\title{
O QUE É ICONOCLASH? OU, HÁ UM MUNDO ALÉM DAS GUERRAS DE IMAGEM?*
}

\author{
Bruno Latour \\ Instituto de Estudos Políticos de Paris - França
}

Resumo: O autor oferece uma reflexão a partir das obras apresentadas na exposição Iconoclash. Beyond the Image Wars in Science, Religion and Art, em 2002, no Center for New Art and Media, em Karlsruhe, cuja curadoria juntou três ambientes, os da religião, da ciência e da arte contemporânea, em que as imagens vêm se apresentando como "armas culturais" por meio de uma luta ambígua que tanto produz como destrói imagens, ícones e emblemas. Iconoclash foi o termo escolhido para definir a temática dessa exposição e nortear a reflexão do autor sobre o ódio e o fanatismo, nos diversos âmbitos da vida cultural social e política. Movendo-se em direção a um tipo alternativo de "iconofilia", para além das guerras de imagens, sugere a suspensão do gesto iconoclasta optando-se por uma cascata de imagens em transformação, ao invés de se ater obsessivamente a imagens fixas e congeladas fora de seu fluxo. ${ }^{* *}$

Palavras-chave: arte, ciência, imagem, religião.

Abstract:The author offers a reflection based on the works presented at the exhibit Iconoclash. Beyond the Image Wars in Science, Religion and Art, at the Center for New Art and Media, in Karlsruhe in 2002, where the curators put together three fields religion, science and contemporary art, in which images have been presented as "cultural weapons" through an ambiguous struggle that both produces and destroys images, icons and emblems. Iconoclash was the term chosen to define the theme of this exhibition and guide the author's reflection on hatred and fanaticism, in the diverse

\footnotetext{
* Tradução para o português da versão original em inglês What is Iconoclash? Or Is There a World Beyond the Image Wars?, introdução do catálogo da exposição Iconoclash. Beyond The Image Wars in Science, Religion and Art, realizada no Center for New Art and Media, em Karlsruhe, Alemanha, 2002. A versão em inglês desta introdução encontra-se disponível no site do autor (Latour, 2002). (N. de E.).

** Resumo de autoria dos organizadores. (N. de E.).
} 
ambits of the cultural, social and political life. Moving towards an alternative type of "iconophilia", beyond the image wars, the author suggests the suspension of the iconoclast gesture, opting for a cascade of images in transformation, instead of focusing obsessively on images fixed and frozen out of their flow.

Keywords: art, image, religion, science.

\section{Prólogo: um típico iconoclash'}

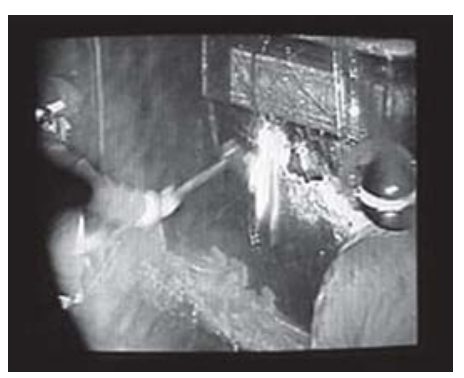

Esta imagem vem de um vídeo. O que significa? Hooligans vestidos de vermelho, com capacetes e machados, estão despedaçando a janela reforçada que protege uma preciosa obra de arte. Eles estão batendo enlouquecidamente no vidro, que se estilhaça em todas as direções enquanto altos gritos de horror às suas ações são ouvidos da multidão em torno deles, que, não importa quão furiosa, permanece incapaz de parar a pilhagem. Outro triste caso de vandalismo, capturado por uma câmera de vigilância? Não. Corajosos bombeiros italianos, alguns anos atrás, arriscando suas vidas, na catedral de Turim, para salvar o famoso Sudário de um incêndio devastador que provoca os gritos de horror da multidão impotente que se juntou atrás deles. Em seus uniformes vermelhos e seus capacetes protetores, eles tentam quebrar com machados a caixa de vidro fortemente reforçada que foi construída em volta do linho sagrado, para protegêlo - não do vandalismo - mas da louca paixão dos devotos e peregrinos a quem nada deteria até que o rasgassem em pedaços para obter relíquias preciosas. A caixa é tão bem protegida contra os devotos, que não pode ser colocada em segurança, longe do fogo intenso, sem esse ato aparentemente violento de quebrar o vidro. Iconoclasmo é quando sabemos o que está acontecendo no

${ }^{1}$ Iconoclash [icon = 'ícone', clash $=$ 'choque, embate'] pode ser traduzido como iconochoque. Todavia, em respeito à sonoridade e ao jogo de palavras intraduzível do original - em paralelismo e em contraste com iconoclasm [iconoclasmo] - optou-se por manter o termo em inglês. (N. de E.).

Horizontes Antropológicos, Porto Alegre, ano 14, n. 29, p. 111-150, jan./jun. 2008 
ato de quebrar e quais são as motivações para o que se apresenta como um claro projeto de destruição; iconoclash, por outro lado, é quando não se sabe, quando se hesita, quando se é perturbado por uma ação para a qual não há maneira de saber, sem uma investigação maior, se é destrutiva ou construtiva. Esta exposição é sobre iconoclash, não sobre iconoclasmo.

\section{Por que as imagens provocam tanta paixão?}

Freud está totalmente certo ao insistir no fato de que estamos lidando, no Egito, com a primeira contra-religião da história da humanidade. É aqui que, pela primeira vez, foi feita [por Akhenaton] a distinção que provocou o ódio daqueles excluídos por ela. É a partir dessa distinção que o ódio existe no mundo, e a única maneira de ir além dela é voltar às suas origens. (Assman, 2001, p. 283). ${ }^{2}$

Nenhuma citação poderia resumir melhor o que vejo como o objetivo de iconoclash. (Devo de saída alertar o leitor quanto ao fato de que nenhum dos curadores concorda completamente com os objetivos desta exposição! Como editor, eu só tenho o privilégio de dar primeiro a minha opinião.) O que propomos aqui, nesta mostra e neste catálogo, é uma arqueologia do ódio e do fanatismo. ${ }^{3}$

Por quê? Porque estamos cavando em busca da origem de uma distinção absoluta - e não relativa - entre verdade e falsidade, entre um mundo puro, absolutamente esvaziado de intermediários feitos pelo homem e um mundo repulsivo, composto de mediadores feitos pelo homem, impuros, porém fascinantes. "Se, ao menos”, alguns dizem, "pudéssemos ficar sem qualquer ima-

2 Retraduzido do francês: "Freud a parfaitement raison d'insister sur le fait que nous avons faire en Egypte à la première contre-religion monothéiste qu'ait connu l'histoire de l'humanité. C'est ici que s'est opérée pour la première fois la distinction qui a attiré sur elle la haine des exclus. C'est depuis lors que la haine existe dans le monde, et le seul moyen de la dépasser est de revenir à ses origines", já que a versão em inglês é bastante diferente: "Freud concentra toda a força contrareligiosa do monoteísmo Bíblico na revolução de Akhenaton acima. Esta foi a origem de tudo. Freud destaca (muito corretamente) o fato de que se está lidando com o primeiro movimento monoteísta, contra-religioso e exclusivamente intolerante deste tipo na história humana. A similaridade desta interpretação com a de Manetho é evidente. É este ódio provocado pela revolução de Akhenaton que informa os textos judeofóbicos da Antigüidade.” (Assmann, 1997, p. 167).

3 Sobre a genealogia dos fanáticos e outros Schwärmer (N. de T.: “visionários”), ver o relato fascinante de Dominique Colas (1992) e Christin Olivier (1991).

Horizontes Antropológicos, Porto Alegre, ano 14, n. 29, p. 111-150, jan./jun. 2008 
gem. Quão melhor, mais puro, mais rápido, seria nosso acesso a Deus, à Natureza, à Verdade, à Ciência.” Ao que outras vozes (ou, às vezes, as mesmas) respondem: "Que pena (ou: felizmente), não conseguimos ficar sem imagens, intermediários, mediadores de todos os jeitos e formas, porque essa é a única maneira de ter acesso a Deus, à Natureza, à Verdade e à Ciência.” Esse é o dilema que queremos documentar, compreender e, talvez, superar. No veemente resumo que Marie-José Mondzain realizou da discussão bizantina sobre as imagens: "La vérité est image mais il n’ya a pas d'image de la vérité" [A verdade é imagem, mas não existe uma imagem da verdade]. ${ }^{4}$

$\mathrm{O}$ que aconteceu, que tornou as imagens (e por imagem queremos dizer qualquer signo, obra de arte, inscrição ou figura que atua como mediação para acessar alguma outra coisa) o foco de tanta paixão? A ponto de destruí-las, apagá-las, desfigurá-las se ter tornado a pedra de toque para provar a validade da fé, da ciência, da perspicácia, da criatividade artística de alguém? A ponto de que ser iconoclasta parece a mais alta virtude, a mais alta piedade em círculos intelectuais?

Além disso, por que é que todos os destruidores de imagens, esses “teoclastas”, esses iconoclastas, “ideoclastas”, geraram também uma fabulosa população de novas imagens, de ícones frescos, mediadores rejuvenescidos: maiores fluxos de mídia, idéias mais poderosas, ídolos mais fortes? Como se a desfiguração de um objeto pudesse inevitavelmente gerar novas faces; como se o desfiguramento e o "refiguramento" fossem necessariamente coetâneos ${ }^{5}$ [ver Belting, Powers]. ${ }^{6}$ Mesmo a minúscula cabeça de Buda - que Heather Stoddard ofereceu para nossa meditação -, depois de ter sido despedaçada pela Guarda Vermelha durante a Revolução Cultural, conseguiu adquirir uma

\footnotetext{
4 Ver o capítulo da autora neste catálogo e Mondzain (1996).

5 Vários séculos depois de Farel, o iconoclasta de Neuchâtel, ter queimado livros e esmagado estátuas da Igreja Católica, ele mesmo foi honrado com uma estátua na frente da igreja, agora esvaziada. Ver a foto e o texto de Léchot neste catálogo. Os mais chocantes casos de substituição de um ídolo por um ícone (ou, dependendo do ponto de vista, de um ídolo por outro ídolo) são descritos em Serge Gruzinski (1988). Quando, durante a conquista espanhola do México, padres pedem a outros padres que coloquem as estátuas da Virgem Maria nos mesmos lugares onde os “ídolos” jaziam esmagados ao chão.

6 Latour faz indicações desse tipo, neste texto, para remeter o leitor a trabalhos que se encontram no catálogo da exposição do qual este texto é apenas a introdução. Essas indicações foram mantidas e aqui aparecem entre colchetes. (N. de E.).
}

Horizontes Antropológicos, Porto Alegre, ano 14, n. 29, p. 111-150, jan./jun. 2008 
nova face, sarcástica, franzida e dolorosa... [ver Stoddard].

E o que aconteceu que possa explicar que, após cada ícono-crise, um cuidado infinito seja posto em ação para restaurar as estátuas despedaçadas, salvar os fragmentos, proteger os escombros? Como se fosse sempre necessário desculpar-se pela destruição de tanta beleza, de tanto horror; como se de repente não se tivesse certeza do papel e da causa da destruição que, antes, parecia tão urgente, tão indispensável; como se o destruidor tivesse, de repente, se dado conta de que algo além houvesse sido destruído por acidente, algo em relação ao qual uma reconciliação fosse agora devida. Não são os museus os templos nos quais sacrifícios são feitos para se pedir desculpas por tanta destruição, como se quiséssemos de repente parar de destruir e estivéssemos começando o culto indefinido de conservar, proteger, reparar?

É isso que nossa exposição tenta fazer: esse cafarnaum de objetos heterogêneos que montamos, quebramos, consertamos, ajeitamos, (re)descrevemos, oferece aos visitantes uma meditação sobre as seguintes questões:

Por que as imagens têm atraído tanto ódio?

Por que elas sempre voltam a retornar, não importa o quanto queiram livrar-se delas?

Por que os martelos dos iconoclastas sempre parecem bater obliquamente, destruindo algo além, que parece, a posteriori, importar imensamente?

Como é possível ir além desse ciclo de fascinação, repulsa, destruição, reconciliação, que é gerado pelo culto à imagem proibida?

\section{Uma exposição sobre iconoclasmo}

Ao contrário de muitas tentativas similares, esta não é uma exposição iconoclasta: ela é sobre iconoclasmo. ${ }^{7}$ Ela pretende suspender a ânsia de des-

\footnotetext{
Ver, por exemplo, a exibição de Berna e Estrasburgo em 2001 (Dupeux et al., 2001). A exposição de Berna foi inteiramente construída em honra aos corajosos destruidores de ícones que haviam libertado a cidade do poder da imagem para levar ao simbolismo superior da cruz... até um diorama onde figuras de cera derretiam cálices e relicários inúteis para moldar úteis moedas de ouro suíças! Mas em um ótimo iconoclash a última sala mostrava os resquícios permanentes das estátuas quebradas que haviam sido transformadas de ídolos hediondos em obras de arte piamente conservadas! Nenhuma indicação era dada aos visitantes de qualquer iconoclash possível... A mesma piedade iconoclástica pode ser vista na recente exposição do Louvre de Régis Michel chamada La peinture comme crime, Réunions des musées nationaux, Paris, 2002.
}

Horizontes Antropológicos, Porto Alegre, ano 14, n. 29, p. 111-150, jan./jun. 2008 
truir imagens, nos pede para parar por um momento; deixar o martelo descansar. Ela reza para que um anjo venha e segure nosso braço sacrificial que empunha a faca sacrificial pronta para cortar a garganta do cordeiro sacrificial. É uma tentativa de voltar, de envolver, de encerrar o culto da destruição da imagem; dar a ela uma casa, um lugar, um espaço de museu, um lugar de meditação e surpresa. Ao invés de o iconoclasmo ser uma metalinguagem reinando como um mestre sobre todas as outras linguagens, é o culto ao próprio iconoclasmo que, por sua vez, é interrogado e avaliado. De um recurso, o iconoclasmo é convertido em um tópico. Nas palavras propostas pelo belo título de Miguel Tamen: nós queremos que os visitantes e os leitores se tornem “amigos de objetos interpretáveis" (ver Tamen, 2001).

De certo modo, esta exposição tenta documentar, expor, fazer a antropologia de um certo gesto, de um certo movimento da mão. O que significa dizer de alguma mediação, de alguma inscrição, que ela é um produto humano?

Como é bem sabido por historiadores da arte e teólogos, muitos ícones sagrados que têm sido celebrados e cultuados são chamados acheiropoiete; ou seja, não feitos por mãos humanas [ver Koerner, Mondzain]. Faces de Cristo, retratos da Virgem, o véu de Verônica; existem muitos exemplos desses ícones que caíram do céu, sem intermediários. Mostrar que um humilde pintor humano os fez seria enfraquecer sua força, manchar sua origem, dessacralizálos. Além disso, acrescentar a mão às pinturas é equivalente a estragá-las, criticá-las. O mesmo é verdade com relação à religião em geral. Se alguém diz que ela é feita pelo homem, anula a transcendência das divindades, esvazia a afirmação de uma salvação do além.

De maneira mais geral, a mente crítica é a que mostra as mãos dos humanos agindo em todos os lugares, a fim de trucidar a santidade da religião, a crença nos fetiches, o culto ao transcendente, os ícones mandados do céu, a força das ideologias. Quanto mais se puder ver que a mão humana trabalhou em uma imagem, mais fraca será a pretensão da imagem de oferecer verdade (ver o exemplo prototípico de Tintin). Desde a Antigüidade, os críticos nunca se cansaram de denunciar os esquemas tortuosos de humanos que tentam fazer os outros acreditarem em fetiches que não existem. O truque para desvendar o truque é sempre mostrar a baixa origem do trabalho, o manipulador, o contraventor, o fraudador por baixo do pano, pego em flagrante.

O mesmo é válido em relação à ciência. Também ali a objetividade deve supostamente ser acheiropoiete, não feita por mão humana. Se alguém mostra que há mãos a trabalhar no tecido humano da ciência, é acusado de man- 
char a santidade da objetividade, de arruinar sua transcendência, de proibir qualquer desejo de verdade, de pôr fogo à única fonte de iluminação que podemos ter [ver Lévy-Leblond]. Nós tratamos como iconoclastas aqueles que falam dos humanos que trabalham - cientistas em seus laboratórios - por trás ou por sob as imagens que geram a objetividade científica. Eu também fui presa desse iconoclash paradoxal: a nova reverência às imagens da ciência é considerada sua destruição. A única maneira de defender a ciência das acusações de falsificação, de evitar o rótulo de "socialmente construída”, é, aparentemente, insistir em que mão alguma jamais tocou na imagem que produziu (ver Daston; Galison, 2001; Galison, 1998). Assim, em ambos os casos, da religião e da ciência, quando a mão é mostrada a trabalhar, ela é sempre a mão que segura o martelo ou o archote: sempre mão crítica, destruidora.

Mas e se as mãos forem realmente indispensáveis para alcançar a verdade, para produzir objetividade, para fabricar divindades? O que aconteceria se, ao dizer que determinada imagem é produto humano, estivéssemos aumentando, não diminuindo, a reivindicação de verdade? Seria o término da disposição crítica, o fim do antifetichismo. Poderíamos dizer, contra ímpeto crítico, que quanto mais humanos há, mais o trabalho humano se mostra, melhor a apreensão da realidade, da santidade, da devoção. Que quanto mais imagens, mediações, intermediários e ícones se multiplicam e são abertamente fabricados, quanto mais eles são explícita e publicamente construídos, mais respeito temos por sua capacidade de acolher, reunir, recolher a verdade e a santidade (religere ${ }^{8}$ é uma das muitas etimologias da palavra religião). É como Mick Taussig mostrou, de forma tão bela: quanto mais se revelam os truques necessários para convidar os deuses para a cerimônia durante a iniciação, mais forte a certeza de que as divindades estão presentes (Taussig, 1999). Longe de desfazer o acesso aos seres transcendentes, revelar a labuta humana, os truques, reforça a qualidade desse acesso [ver Sarrô, de Aquino].

Portanto, podemos definir um iconoclash como aquilo que ocorre quando há incerteza a respeito do papel exato da mão que trabalha na produção de um mediador. É a mão com um martelo pronto para expor, denunciar, desbancar, desmascarar, mostrar, desapontar, desencantar, dissipar as ilusões de alguém,

8 Do latim, significando “conexão”. (N. de T.). 
para deixar o ar correr? Ou é, ao contrário, uma mão cautelosa e cuidadosa, com a palma virada como se fosse pegar, extrair, trazer à luz, saudar, gerar, entreter, manter, colher verdade e santidade?

Mas aí, é claro, o segundo mandamento já não pode ser obedecido: "Não farás para ti imagem de escultura, nem figura alguma de tudo o que há no alto do céu, ou em baixo na terra, ou que está debaixo da terra nas águas” (Deuteronômio, 5:8). ${ }^{9}$ Não há necessidade de evasivas quanto à intenção e à tensão desta exposição, tal como a imaginamos nos últimos quatro anos: ela é sobre o segundo mandamento. Temos certeza de que o entendemos corretamente? Será que cometemos um longo e terrível erro sobre seu significado? Como podemos conciliar essa demanda por uma sociedade, uma religião e uma ciência totalmente anicônicas com a fabulosa proliferação de imagens que caracteriza as nossas culturas recheadas de mídia?

Se as imagens são tão perigosas, por que temos tantas? Se elas são inocentes, por que causam tantas e tão duradouras paixões? Tal é o enigma, a hesitação, o quebra-cabeça visual, o iconoclash que desejamos colocar sob os olhos do visitante e do leitor.

\section{Religião, ciência e arte: três padrões diferentes de construção de imagem}

O experimento que planejamos consiste em juntar três fontes de iconoclashes: religião, ciência e arte contemporânea. Queremos situar os muitos eventos, lugares, obras e exemplos, apresentados neste catálogo e nesta exposição, em meio à tensão criada por esse arranjo triangular.

Embora iconoclash reúna grande porção de material religioso, não é uma peregrinação teológica; embora apresente muitas inscrições de tipo científico, não é um museu de ciências para maravilhar pedagogicamente; embora agrupe numerosas obras de arte, não é uma mostra de arte. Cada um de nós - visitantes, curadores e leitores - traz consigo um padrão muito diferente de crença, raiva, entusiasmo, admiração, dúvida, fascinação, suspeita e despeito por cada

9 Todas as citações bíblicas em português, que constam na tradução deste texto, estão em conformidade com tradução bíblica autorizada e foram retiradas da edição brasileira da Bíblia publicada pela Edição Barsa, 1968. (N. de E.). 
um dos três tipos de imagens, e é por essa razão que queremos fazer com que sejam mutuamente relevantes. O que nos interessa é o padrão ainda mais complexo criado pela sua interferência.

\section{Ícones e ídolos}

Mas por que trazer tantos ícones religiosos para esta mostra? Eles já não foram esvaziados pelo julgamento estético, absorvidos pela história da arte, tornados rotina pela piedade convencional, a ponto de estarem mortos para sempre? Ao contrário: basta lembrar as reações à destruição dos Budas de Bamiyan pelos talibãs, no Afeganistão, para nos darmos conta de que as imagens religiosas são ainda as que atraem as paixões mais ferozes [ver Centlivres, 2001; Frodon; Clement]. Do "teoclasta" de Akhenaton em diante, destruir monastérios, igrejas e mesquitas, e queimar fetiches e ídolos em fogueiras enormes é ainda uma ocupação diária para imensas massas no mundo inteiro, exatamente como no tempo do que Assman chama de "distinção mosaica” [ver Pietz, Corbey, Taylor]. "Mas destrói os seus altares, quebra as suas estátuas, corta os seus bosques sagrados” (Êxodo, 34:13): a instrução para queimar os ídolos é tão presente, tão candente, tão impetuosa, tão subterrânea como os rios de lava, sempre ameaçadores, do Etna. Mesmo no caso hilariante da destruição, neste verão, do "Mandarom” - uma estátua gigantesca e horrenda, erguida por uma seita no Sul da França - cuja destruição os crentes compararam à aniquilação dos Budas afegãos.

E, obviamente, a destruição de ídolos não está de forma alguma limitada às mentes religiosas. Que crítico não acredita que seu mais importante dever, seu mais urgente compromisso, é destruir os totens, expor as ideologias, desenganar os idólatras? Como muitas pessoas notaram, 99 por cento daqueles que se escandalizaram com o gesto de vandalismo dos talibãs descendem de ancestrais que deixaram em pedaços os ícones mais preciosos de algum outro povo - ou, em verdade, participaram eles mesmos de algum ato de desconstrução [ver Nathan, Koch].

O que tem sido mais violento: o desejo religioso de destruir ídolos para trazer a humanidade ao culto certo do Deus verdadeiro, ou o desejo anti-religioso de destruir os ídolos sagrados e trazer a humanidade ao seu perfeito juízo? É, de fato, um iconoclash, pois, ainda que eles não sejam nada, ninguém sabe se esses ídolos podem ser quebrados sem quaisquer conseqüências ("São ape- 
nas pedras”, disse o mulá Omar, ${ }^{10}$ assim como os iconoclastas bizantinos e, posteriormente, os iconoclastas luteranos), ou se eles devem ser destruídos porque são tão poderosos, tão portentosos ("Se eles são tão vazios, por que vocês os levam a sério?”; “Seu ídolo é o meu ícone.”) [ver Koerner, Christin].

\section{Inscrições científicas}

Mas por que, afinal, imagens científicas? Certamente, elas oferecem representações do mundo que são frias, não-mediadas, objetivas, e portanto não podem despertar a mesma paixão e frenesi que as figuras religiosas. Ao contrário destas, as imagens científicas simplesmente descrevem o mundo de maneira demonstravelmente verdadeira ou falsa. Precisamente porque são frias, elas são sempre novas [fresh] e podem ser verificadas, elas são largamente incontroversas, são o objeto de uma concordância rara, quase universal. Então o padrão de confiança, crença, rejeição e rancor em relação a elas é inteiramente diferente daquele gerado pelos ídolos/ícones. É por isso que há tantas delas aqui, e, como iremos ver, por isso que elas oferecem tantos tipos diferentes de iconoclashes.

Para começar, para muitas pessoas, elas nem são imagens, mas o mundo em si. Não haveria nada a dizer sobre elas, apenas aprender sua mensagem. Chamá-las de imagem, inscrição, representação, deixá-las em exposição lado a lado com ícones religiosos, já é um gesto iconoclástico. "Se estas são meras representações de galáxias, átomos, luz, genes, então poder-se-ia dizer, indignadamente, que elas não são reais, que elas foram fabricadas.” E no entanto, como ficará visível aqui [ver Galison, Macho, Huber, Rheinberger], aos poucos fica mais claro que, sem instrumentos enormes e caríssimos, grandes grupos de cientistas, vastas quantias de dinheiro, longo treinamento, nada seria visível naquelas imagens. É por causa de tantas mediações que elas são capazes de ser tão objetivamente verdadeiras.

\footnotetext{
10 “Ou essas estátuas estão associadas a crenças idólatras, comentou o mulá, ou são apenas pedras; no primeiro caso, o Islã ordena que se as destrua, no segundo, que importa que sejam quebradas?” [“Ou ces statues sont liées à des croyances idolâtres, a commenté le Mollah, ou il ne s’agit que de simples cailloux; dans le premier cas, l'islam commande de les détruire, dans le second, qu'importe qu'on les brise”] (Centlivres, 2001, p.141).
}

Horizontes Antropológicos, Porto Alegre, ano 14, n. 29, p. 111-150, jan./jun. 2008 
Aqui está outro iconoclash, o exato oposto daquele erguido pelo culto da destruição da imagem religiosa: quanto mais instrumentos, mais mediação, meIhor a apreensão da realidade [ver Schaffer]. Se há um domínio no qual o segundo mandamento não pode ser aplicado, é aquele governado pelos que configuram objetos, mapas e diagramas na forma "de tudo o que há no alto do céu, ou em baixo na terra, ou que está debaixo da terra nas águas” (Deuteronômio, 5:8). Então, o padrão de interferência pode permitir-nos renovar nossa compreensão da construção da imagem: quanto mais imagens humanamente produzidas forem geradas, mais objetividade se colherá. Na ciência, não há algo que seja "mera representação".

\section{Arte contemporânea}

Então por que ligar mediações religiosas e científicas à arte contemporânea? Porque aqui ao menos não há dúvida de que pinturas, instalações, happenings, eventos e museus são humanamente produzidos. A mão que trabalha é visível em todos os lugares. Não se espera que surja nenhum ícone acheiropoiete desse grande redemoinho de movimentos, artistas, promotores, compradores e vendedores, críticos e dissidentes. Ao contrário, as reivindicações mais extremas vêm sendo feitas em nome de uma criatividade individual, baseada no homem. Nada de acesso à verdade ou às divindades. Abaixo a transcendência! [ver Belting, Groys, Weibel].

Em nenhum outro lugar, a não ser na arte contemporânea, há melhor laboratório, montado para tentar e testar a resistência de cada item que compõe o culto da imagem, da figura, da beleza, da mídia, do gênio. Em nenhum outro lugar tantos efeitos paradoxais foram produzidos e lançados ao público para complicar sua reação às imagens [ver Gamboni, Heinich]. Em nenhum outro lugar tantos esquemas foram inventados para retardar, modificar, perturbar, perder o olhar ingênuo e o "regime escópico" do amateur d'art [ver Yaneva, Lowe]. Tudo vem sendo lentamente confrontado em experimentos e feito em pedaços, desde a representação mimética, passando pela construção de imagem, a tela, a cor, o trabalho artístico, até o próprio artista, sua assinatura, o papel dos museus, dos patrocinadores, dos críticos - para não esquecer os filistinos, ridicularizados ao extremo.

Tudo e todos, qualquer detalhe do que a arte é e do que é um ícone, um ídolo, uma vista, um olhar, foram jogados na panela para serem cozinhados e 
queimados ao longo do século passado, no que foi chamado de arte modernista. ${ }^{11}$ Um Juízo Final foi promulgado: todas as nossas maneiras de produzir representação de qualquer tipo foram consideradas deficientes. Gerações de iconoclastas despedaçando mutuamente seus trabalhos e rostos. Um fabuloso experimento niilista em larga escala [ver Sloterdijk, Weibel]. Uma alegria maníaca na autodestruição. Um sacrilégio hilariante. Uma espécie de inferno anicônico e deletério.

E no entanto, é claro, como seria de se esperar, há aqui outro iconoclash: tanto desfiguramento e tanto “(re)figuramento" [ver Obrist, Tresch, Lowe]. Desse experimento obsessivo para evitar o poder da construção tradicional da imagem, uma fonte fabulosa de novas imagens, novas mídias, novas obras de arte foi encontrada; novos esquemas para multiplicar as possibilidade de visão. Quanto mais a arte se tornou sinônimo de destruição da arte, mais arte vem sendo produzida, avaliada, comentada, comprada e vendida, e, sim, cultuada. Novas imagens vêm sendo produzidas, tão poderosas que tem sido impossível comprá-las, tocá-las, queimá-las, arrumá-las e mesmo transportá-las, gerando assim ainda mais iconoclashes... [ver Gamboni]. Uma espécie de "destruição criativa” que Schumpeter não havia previsto.

\section{Um reembaralhamento da confiança e da desconfiança em relação à imagem}

Assim, juntamos três diferentes padrões de rejeição e de construção de imagem, de confiança e desconfiança na imagem. Nossa aposta é que a interferência entre os três deveria nos levar além das guerras de imagem, além do Bildersturm.

Não trouxemos imagens religiosas para uma instituição de vanguarda de arte contemporânea para mais uma vez submetê-las a ironia ou destruição, nem para novamente apresentá-las como objeto de culto. Elas foram trazidas aqui para ressoarem com as imagens científicas e mostrarem de que maneiras elas são poderosas e que espécie de invisibilidade ambos os tipos de imagens têm sido capazes de produzir [ver Koerner, Mondzain].

Não trouxemos as imagens científicas para instruir ou iluminar o público de uma maneira pedagógica, mas para mostrar como elas são geradas e como

\footnotetext{
${ }^{11}$ Ver, a esse respeito, o magnífico trabalho de Tim J. Clark (1999).
} 
elas se conectam, a que espécie de iconoclasmo elas têm sido sujeitadas [ver Galison, Schaffer], que tipo peculiar de mundo invisível elas geram.

Quanto às peças de arte contemporâneas aqui expostas, elas não compõem uma mostra de arte, mas, sim, vêm traçar as conclusões desse enorme experimento de laboratório sobre os limites e virtudes da representação, que vem se dando em tantos meios e através de tantas empreitadas ousadas e inovadoras [ver Weibel].

Com efeito, estamos tentando construir, para a arte iconoclasta recente, uma espécie de câmara para os ídolos, similar àquelas feitas pelos profanadores protestantes quando removeram as imagens do culto, tornando-as objetos de horror e escárnio, antes que se tornassem os primeiros núcleos do museu de arte e da apreciação estética [ver Koerner]. Uma pequena reviravolta, com certeza, e mais do que um pouco irônica - mas muito bem-vinda.

Os padrões rotineiros de respeito, espanto, desconfiança, devoção e confiança, que geralmente distinguem as mediações religiosas, científicas e artísticas, deverão se redistribuir através desta mostra.

\section{Que objeto selecionar?}

Como já deve estar claro agora, iconoclash não é nem uma mostra de arte nem um argumento filosófico, mas um gabinete de curiosidades, curiosidades reunidas por "amigos de objetos interpretáveis" para sondar a fonte do fanatismo, ódio e niilismo gerados pela questão da imagem na tradição ocidental. Um projeto pequeno, se tanto! Mas, já que os curadores desta mostra não são totalmente loucos, não tentamos cobrir toda a questão da devoção e destruição da imagem, desde o Akhenaton até o 11 de setembro. Nosso empreendimento não é enciclopédico. Ao contrário, nós, muito seletivamente, escolhemos apenas os lugares, objetos e situações em que há uma ambigüidade, uma hesitação, um iconoclash quanto a como interpretar a construção da imagem e a destruição da imagem.

Cada um dos curadores tem um diferente princípio de seleção, e o apresenta a seguir; vou então declarar o meu princípio da forma mais clara possível: estou interessado em representar o estado de espírito daqueles que destruíram fetiches - ou o que prefiro chamar de fe(i)tiches ou factiches (Latour, 1996, 1998, 1999) - e que entraram no que Assmann chama de "contra-religião.” 


\section{Um dilema impossivel}

Como eles suportam viver com os pedaços do que tinha sido, até que eles chegassem, a única maneira de produzir, de reunir, de saudar as divindades? Quão assustados devem ficar ao olharem para as suas mãos, que não são mais capazes de completar as tarefas em que, por eras, foram bem-sucedidas, a saber: ocupar-se em um trabalho e ainda assim gerar objetos que não são feitos por elas próprias? Agora eles têm de escolher entre duas demandas contraditórias: isso vocês fizeram com suas próprias mãos, e nesse caso não tem valor; ou isso é objetivo, verdadeiro, transcendente, e, sendo assim, vocês jamais poderiam tê-lo feito. Ou bem Deus está fazendo tudo e os humanos não fazem nada, ou então os humanos estão fazendo todo o trabalho e Deus não é nada. Excesso, ou demasiada escassez, quando os fetiches se vão.

Ainda assim, é claro, os fetiches têm de ser feitos. As mãos humanas não podem parar de trabalhar, produzindo imagens, figuras, inscrições de todas as espécies, para continuar a gerar, saudar e colher objetividade, beleza e divindades, exatamente como nos - agora proibidos - velhos tempos reprimidos e obliterados. Como poderia alguém não se tornar um fanático, se os deuses, as verdades e a santidade têm de ser feitos e se já não há nenhuma maneira legítima de fazê-los? Minha pergunta ao longo desta exposição é: como se pode viver com esse dilema sem enlouquecer? Nós enlouquecemos? Há uma cura para este devaneio?

Vamos contemplar por um momento a tensão criada por este dilema, que pode explicar muito da arqueologia do fanatismo. Ao esmagador de ídolos, ao destruidor de mediadores, restam somente dois opostos polares: ou ele (parece-me justo deixar no masculino) está em pleno comando de suas mãos, mas então o que ele produziu é "simplesmente" a "mera" conseqüência de sua própria força e fraqueza projetadas na matéria - já que ele é incapaz de produzir mais output do que teve de input - e nesse caso ele só pode alternar entre hybris e desespero, conforme enfatize seu poder criativo infinito ou suas forças absurdamente limitadas.

Ou então ele está nas mãos de uma divindade transcendente, não-criada, que o criou do nada e produz verdade e santidade da maneira acheiropoietica. E da mesma maneira que ele, o fabricante humano, alterna entre hybris e desespero, Ele, o Criador, vai alternar loucamente entre onipotência e não-existência, conforme Sua presença possa, ou não, ser mostrada e Sua eficácia, pro- 
vada. O que costumava ser sinônimo - "eu faço" e "eu não estou no controle do que faço” - tornou-se uma contradição radical: “Ou você faz ou você é feito”. ${ }^{12}$

Essa alternância brutal entre exercer o comando como um poderoso (impotente) criador humano ou estar nas mãos de um onipotente (impotente) Criador já é bastante ruim; mas pior ainda, o que realmente complica o duplo vínculo do dilema e coloca o humano, já em camisa-de-força, num frenesi extremo, é que não há jeito de parar a proliferação de mediadores, inscrições, objetos, ícones, ídolos, imagem, figura e signos - apesar da sua interdição. Não importa quão inflexível se possa ser em relação a quebrar fetiches e impor a si mesmo a proibição do culto às imagens: templos serão construídos, sacrifícios serão feitos, instrumentos serão empregados, escrituras serão cuidadosamente redigidas, manuscritos serão copiados, incenso será queimado, e milhares de gestos terão de ser inventados para coletar verdade, objetividade e santidade [ver Tresch no caso notável de Francis Bacon, Halberthal no triste caso do templo de Jerusalém].

O segundo mandamento é ainda mais terrível por não haver como obedecê-lo. A única coisa que se pode fazer para fingir respeitá-lo é negar o trabalho das próprias mãos, reprimir a ação sempre presente na feitura, fabricação, construção e produção de imagens, é apagar a escrita ao mesmo tempo que se escreve, bater nas próprias mãos ao mesmo tempo em que se está manufaturando. E sem mãos, o que você pode fazer? Sem imagem, a qual verdade você terá acesso? Sem instrumento, que ciência dará a você instrução?

Podemos medir o infortúnio enfrentado por aqueles que têm de produzir imagens e que estão proibidos de confessar que as estão fazendo? Pior: ou eles terão de dizer que o demiurgo está fazendo todo o trabalho, escrevendo as escrituras sagradas diretamente, inventando os rituais, ordenando a lei, juntando as multidões, ou então, se o trabalho do fiel é revelado, nós seremos forçados a denunciar aqueles textos como "meras" fabricações, aqueles rituais como faz-de-conta, sua feitura [making] como invenção [making up], suas construções como um embuste, sua objetividade como socialmente construída, suas leis como simplesmente humanas, demasiado humanas. ${ }^{13}$

\footnotetext{
${ }^{12}$ Ver um caso chocante na fábula de La Fontaine Le statuaire et la statue de Jupiter (livre neuvième, fable VI); [ver Gamboni] para outra interpretação.

${ }^{13}$ Ver Jean-François Clément (1995). Para uma investigação cuidadosa sobre o "ciúme” de Deus Criador em relação ao artista e a possibilidade constante de ateísmo na rejeição maníaca de ídolos, ver o catálogo.
} 
Então o esmagador de ídolos é duplamente louco: não só ele se privou do segredo para produzir objetos transcendentes, como também continua a produzi-los ainda que essa produção tenha se tornado absolutamente proibida, sem possibilidade de registro. Ele não só hesita entre poder infinito e fraqueza infinita, liberdade criativa infinita e dependência infinita da mão de seu Criador, mas também alterna constantemente entre a negação dos mediadores e sua presença necessária. É o bastante para enlouquecer a pessoa. Suficiente, ao menos, para produzir mais de um iconoclash.

Freud, no seu estranho pesadelo sobre Moisés, se propôs a explicar uma loucura similar - a invenção da "contra-religião" - uma lenda das mais bizarras, a do assassinato do pai egoísta e dominador pela horda primitiva de seus filhos ciumentos (Freud, 1996). Mas a tradição oferece outra lenda, mais reveladora, na qual não é o pai que é morto, mas os meios de subsistência do pai que são deixados em pedaços pelo seu filho superempreendedor. ${ }^{14}$

Diz-se que Abraão, aos seis anos de idade, destruiu a oficina de ídolos de seu pai, Terah, quando ela estava temporariamente a seu encargo (ver o anexo). Que ótimo iconoclash! Até hoje ninguém entende a resposta ambígua do pai à questão do filho: "Por que seu ouvido não escuta aquilo que a sua boca diz?” É o filho recriminando o pai pelo seu culto aos ídolos ou é, ao contrário, o pai que está recriminando o filho por não entender o que os ídolos podem fazer [ver Nathan]? Se você começar a destruir os ídolos, meu filho, com quais mediações você vai saudar, coletar, acessar, compor e juntar suas divindades? Você tem certeza de que entende os preceitos do seu Deus? Que espécie de loucura você vai adentrar se começar a acreditar que eu, seu pai, ingenuamente acredito nestes ídolos que fiz com minhas próprias mãos, cozi em meu próprio forno, esculpi com minhas próprias ferramentas? Você realmente acredita que eu ignoro a sua origem? Você realmente acredita que essa origem baixa enfraquece a reivindicação de realidade? Sua mente crítica é tão ingênua assim?

Essa lendária discussão pode ser vista em todos os lugares em termos mais abstratos, sempre que uma mediação produtiva é quebrada em pedaços e

\footnotetext{
${ }^{14}$ A diferença entre os dois tipos de assassinato pode explicar alguns dos estranhos aspectos visuais do gabinete de Freud. Ver Marinelli [no catálogo], e mais amplamente o que Andreas Mayer [no catálogo] chama de “objetos psíquicos.”
}

Horizontes Antropológicos, Porto Alegre, ano 14, n. 29, p. 111-150, jan./jun. 2008 
substituída pela questão: "Isso é feito ou isso é real? Você tem que escolher!”15 O que tornou o construtivismo impossível na tradição ocidental? Uma tradição que, por outro lado, construiu e descontruiu tanto, mas sem ser capaz de confessar como foi capaz de fazê-lo. Se os ocidentais tivessem realmente acreditado que tinham de escolher entre construção e realidade (se eles tivessem sido consistentemente modernos), eles nunca teriam tido religião, arte, ciência e política. Mediações são necessárias em todos os lugares. Se alguém as proíbe, você pode se tornar louco, fanático, mas não há maneira de obedecer a ordem e escolher entre opostos bipolares: ou é feito, ou é real. Essa é uma impossibilidade estrutural, um impasse, um dilema, um frenesi. É tão impossível quanto pedir ao manipulador dos bonecos no bunraku que escolha, de agora em diante, entre mostrar seu fantoche ou se mostrar a si mesmo no palco.

\section{Aumentar o custo da crítica}

Então, de minha parte, selecionei itens que revelam esse dilema e o fanatismo que ele provoca (para o exemplo prototípico que está na origem desta mostra, ver o anexo “Abraão e a Oficina de Ídolos de seu Pai Terah”) (Murthy, 1996). É como se a mente crítica não pudesse superar a quebra original dos "factiches" 16 e se desse conta de quanto perdeu ao forçar o fabricador a uma escolha impossível entre a construção humana e o acesso à verdade e à objetividade. A suspeita nos deixou idiotas. É como se o martelo da crítica tivesse voltado e batido insensivelmente na cabeça do crítico!

É por isso que esta exposição é também uma revisão do espírito crítico, uma pausa na crítica, uma meditação sobre a ânsia de desmarcarar, de apressadamente atribuir crença ingênua aos outros [ver Koch] (Sloterdijk, 1987). Os devotos não são idiotas [ver Schaffer]. Não é que a crítica não seja mais necessária, mas, sim, que ela se tornou, ultimamente, muito vulgar.

\footnotetext{
${ }^{15}$ Em nenhum lugar isso é mais claro que nos estudos científicos, meu campo original, onde se organiza toda e qualquer posição entre realismo e construtivismo; ver Ian Hacking (1999).

${ }^{16}$ Latour propõe o termo faitishe, mesclando as palavras fetishe e fait (fato/feito); aqui, como alternativa à tradução $f e(i) t i c h e$, propõe-se factiche [mais próximo, inclusive, da versão em inglês no texto do autor: factishe] em que as letras fact remetem a fatos/factos (latim factu) e também ao feito (latim factum). (N. de E.).
} 
Poder-se-ia dizer, com mais do que uma pequena dose de ironia, que tem havido uma espécie de miniaturização dos esforços críticos: o que nos séculos passados requereu o formidável esforço de um Marx, um Nietzsche, um Benjamin, se tornou acessível por nada, muito semelhantemente ao que se deu com os supercomputadores dos anos 1950, que costumavam encher salas enormes e gastar uma quantidade enorme de eletricidade e calor, e são agora acessíveis por uma moedinha e não maiores que uma unha. Você pode agora ter a sua desilusão baudrillardiana ou bourdiana por uma canção, sua desconstrução derridiana por um níquel. A teoria da conspiração não custa nada para ser produzida, a descrença é fácil, desbancando o que se aprende em aulas de primeiro semestre de teoria crítica. Como o anúncio recente de um filme de Hollywood proclamou, "Todo mundo é suspeito... todo mundo está à venda... e nada é verdade!”

Gostaríamos (eu gostaria) de tornar a crítica mais difícil, de aumentar seu custo, adicionando outra camada a ela, outro iconoclash: e se a crítica tivesse sido não-crítica a ponto de tornar invisível a necessidade de mediação? Qual é o ponto vulnerável do Ocidente, a mola oculta do modernismo, que move seu maquinário? Mais uma vez: e se tivermos entendido mal o segundo mandamento? E se Moisés foi forçado a atenuá-lo, retransmiti-lo numa conexão sem banda larga, por causa da limitação de seu povo?

\section{Uma classificacão grosseira dos gestos iconoclásticos}

Agora que temos alguma idéia de como foi selecionado o material para a mostra e o catálogo, talvez valha a pena para o leitor e para o visitante o benefício de uma classificação dos iconoclashes aqui apresentados. É obviamente impossível propor uma tipologia padronizada, consensual, para um fenômeno tão complexo e elusivo.

Tal coisa pareceria até ir contra o espírito da mostra. Pois, como afirmei, de modo um tanto enfático: não estamos atrás de uma (re)descrição da iconofilia e do iconoclasmo justamente para produzir ainda mais incerteza sobre os tipos de culto de imagem/destruição de imagem com que nos deparamos? Como então poderemos separá-los de modo preciso? Mas, ainda assim, pode ser útil apresentar resumidamente os cinco tipos de gestos iconoclásticos revisitados nesta mostra, com o simples propósito de melhor avaliar a extensão da ambigüidade gerada pelos quebra-cabeças visuais que vínhamos procurando. 
O princípio por detrás desta classificação, reconhecidamente grosseira, é olhar para:

- as intenções íntimas dos destruidores de ícones;

- os papéis que eles dão para as imagens destruídas;

- os efeitos dessa destruição naqueles que apreciavam aquelas imagens;

- como essa reação é interpretada pelos iconoclastas;

- e, finalmente, os efeitos da destruição nos sentimentos do próprio destruidor.

A lista é rudimentar, mas creio que sólida bastante para guiar através dos muitos exemplos reunidos aqui.

\section{As pessoas " $A$ " são contra todas as imagens}

O primeiro tipo - uso letras para evitar qualquer terminologia carregada de conotações - é constituído por aqueles que querem libertar os crédulos - os que eles julgam ser crédulos - do falso vínculo com ídolos de todos os tipos e formas. Ídolos - cujos fragmentos agora jazem por terra - não eram nada mais que obstáculos no caminho que leva a virtudes maiores. Tinham de ser destruídos. Causavam muita indignação e ódio nos corações dos corajosos destruidores de imagens. Viver com eles era insuportável. ${ }^{17}$

O que distingue os As de todos os outros tipos de iconoclastas é que eles acreditam que não só é necessário, mas também possível, prescindir inteiramente de intermediários e ter acesso à verdade, à objetividade e à santidade. Eles pensam que sem estes obstáculos ter-se-á finalmente acesso mais suave, mais rápido, mais direto à coisa real, que é o único objeto digno de respeito e culto. Imagens nem mesmo fornecem preparação, reflexão, uma vaga idéia do original: elas proíbem qualquer acesso ao original. Entre imagens e símbolos, você deve escolher - ou ser amaldiçoado.

\footnotetext{
${ }^{17}$ Como lembrado por Centlivres (ver catálogo), o mulá Omar fez um sacrifício de cem vacas, uma hecatombe muito cara para padrões afegãos, como reparação por ter durante tanto tempo falhado em destruir os Budas: cem vacas para pedir remissão por esse horrível pecado de onze séculos sem os destruir.
} 
O tipo A é então a forma pura do iconoclasmo “clássico”, reconhecível na rejeição, pelo formalista, da imaginação, dos desenhos e modelos [ver Galison], assim como nos muitos movimentos bizantinos, luteranos e revolucionários de despedaçadores de ídolos, e nos horríveis “excessos” da Revolução Cultural [ver Konchok]. A purificação é sua meta. O mundo, para as pessoas A, seria um lugar muito melhor, muito mais limpo, muito mais esclarecido, se fosse possível se livrar de todas as mediações e de um salto pôr-se em contato direto com o original, as idéias, o Deus verdadeiro.

Um dos problemas com os As é que eles têm de acreditar que os outros aqueles coitados, cujos adorados ícones foram acusados de serem ídolos ímpios - acreditam neles ingenuamente. Tal suposição implica que, quando os filistinos reagem com gritos de horror à pilhagem e ao saque, isso não pára os As. Ao contrário, prova quão certos eles estavam [ver Schaffer]. A intensidade do horror dos idólatras é a melhor prova de que aqueles pobres crédulos ingênuos haviam investido demais naquelas pedras que não são, essencialmente, nada. Armados com a noção de crença ingênua, os paladinos da liberdade constantemente se equivocam a respeito da indignação daqueles que eles escandalizam a fim de efetivar um vínculo abjeto a coisas que eles deveriam destruir ainda mais radicalmente.

Mas o problema mais profundo dos As é que ninguém sabe se eles não são Bs!

\section{As pessoas " $B$ " são contra a imagem congelada, não contra imagens}

Os Bs são também destruidores de ídolos. Eles também causam devastação nas imagens, rompem costumes e hábitos, escandalizam os devotos, e provocam os gritos horríveis de “Blasfemo! Infiel! Sacrilégio! Profanação!” Mas a enorme diferença entre os As e os Bs - distinção que percorre toda a exposição - é que estes não acreditam ser possível nem necessário se livrar das imagens. O que eles combatem é o congelamento das imagens, ou seja, extrair uma imagem do fluxo, e se tornar fascinado por ela, como se isso fosse suficiente, como se todo movimento tivesse parado.

O que eles buscam não é um mundo livre de imagens, purificado de todos os obstáculos, livre de todos os mediadores, mas, ao contrário, um mundo cheio de imagens ativas, mediadores em movimento. Eles não querem que a produção de imagens pare para sempre - como os As gostariam - eles querem que ela continue tão rápida e fresca quanto possível. 
Para eles, iconofilia não significa atenção exclusiva e obsessiva à imagem, pois eles não toleram as imagens fixas mais do que os As conseguem tolerar. Iconofilia significa passar de uma imagem para a próxima. Eles sabem que "a verdade é imagem, mas não há uma imagem da verdade.” Para eles, a única maneira de se ter acesso à verdade, à objetividade e à santidade é passando rapidamente de uma imagem para a outra, e não sonhando o sonho impossível de se saltar para um original não-existente. Contrariamente à cadeia platônica de semelhanças, eles nem mesmo tentam passar da cópia ao protótipo. Eles são, como o velho bizantino iconófilo costumava dizer, "econômicos" [ver Mondzain], essa palavra significando, na época, um longo e cuidadosamente organizado fluxo de imagens em religião, política e arte - sem o sentido que tem agora: o mundo dos bens.

Enquanto os As acreditam que aqueles que se atêm às imagens são iconófilos, e que as mentes corajosas que rompem com a fascinação pelas imagens são iconoclastas, os Bs definem iconófilos como aqueles que não aderem a uma imagem em particular, mas são capazes de passar de uma para outra. Para eles, iconoclastas são ou aqueles que absurdamente tentam se livrar de todas as imagens, ou aqueles que permanecem na contemplação fascinada de uma imagem isolada, congelada.

Exemplos prototípicos de Bs poderiam ser: Jesus expulsando os mercadores do Templo; Bach chocando os ouvidos da congregação de Leipzig e expulsando a música obtusa (Taborde, 1992); Malevich pintando o quadrado negro para acessar as forças cósmicas que haviam permanecido escondidas na pintura representacional clássica (Groys, 1990); o sábio tibetano apagando um toco de cigarro numa cabeça de Buda para mostrar seu caráter ilusório (Stoddard, 1985). O dano feito aos ícones é, para eles, sempre uma injunção caridosa para redirecionar a atenção para outras imagens sagradas, mais novas, mais frescas - não para ficar sem imagens.

Mas, claro, muitos iconoclashes vêm do fato de que nenhum cultuador pode saber ao certo quando seu ícone/ídolo favorito vai ser quebrado e jogado ao chão, ou se é um A ou um B quem comete o ato ominoso. Estamos sendo chamados - eles se perguntam - a ficar sem nenhuma mediação e tentar conexões diretas com Deus e a objetividade? Estamos convidados a simplesmente mudar o veículo que até agora vínhamos usando para praticar o culto? Estamos sendo incitados para um sentido renovado de adoração e solicitados a retomar mais uma vez, desde o início, nosso trabalho de construção de imagens? Pensese na longa hesitação daqueles que esperavam ao pé do Monte Sinai o retorno 
de Moisés: o que devemos fazer, o que nos foi pedido? É tão fácil enganar-se a esse respeito e começar a moldar o Bezerro de Ouro [ver Pinchard].

Será que nem os As nem os Bs sabem ao certo como ler as reações daqueles cujos ícones/ídolos estão sendo queimados? Estão furiosos por estarem sem seus ídolos adorados, como crianças pequenas repentinamente privadas de seu objeto transicional? Estão envergonhados por terem sido falsamente acusados de acreditar de modo ingênuo em coisas não existentes? Estão eles horrorizados por serem tão impositivamente levados a renovar a adesão à sua adorada tradição, que eles haviam deixado cair em descrédito, decair em mero costume? Nem os As nem os Bs podem decidir, do estardalhaço dos oponentes, que espécie de profetas eles mesmos são: são eles profetas que pregam o descarte das imagens, ou os que, "economicamente", querem deixar a cascata de imagens mover-se de novo para recomeçar o trabalho de salvação?

Mas este não é o fim de nossa hesitação, de nossa ambigüidade, de nosso iconoclash. As e Bs poderiam, afinal de contas, ser simplesmente Cs disfarçados.

\section{As pessoas " $C$ " não são contra as imagens, exceto as de seus oponentes}

Os Cs também querem desacreditar, desencantar, destruir ídolos. Também eles deixam em seu rastro saques, escombros, gritos de horror, escândalos, abominação, blasfêmia, vergonha e profanação de todos os tipos. Ao contrário dos As e dos Bs, eles não têm nada contra as imagens em geral: eles só se opõem à imagem à qual seus oponentes aderem com mais força.

É o bem conhecido mecanismo de provocação: para destruir alguém com rapidez e eficiência máximas, basta atacar o que é mais adorado, o que se tornou o repositório de todos os tesouros simbólicos de um povo [ver Lindhardt, Sloterdijk]. Bandeiras queimadas, pinturas rasgadas, objetos tomados como reféns são exemplos típicos. Diga-me o que lhe é mais caro, e eu o destruirei para matar você mais rápido. Essa é a estratégia “mini-max” tão característica das ameaças terroristas: máximo dano com mínimo investimento. Abridores de caixas e bilhetes de avião contra os Estados Unidos da América.

A busca pelo objeto apropriado para atrair destruição e ódio é recíproca: “Antes de você querer atacar a minha bandeira, eu não sabia que gostava tanto dela, mas agora eu sei” [ver Taussig]. Portanto, os provocadores e aqueles que eles provocam estão brincando de gato e rato, o primeiro procurando aquilo que com mais rapidez provoca indignação, os outros procurando ansiosamente pelo 
que desencadeará mais violenta indignação. ${ }^{18}$ Durante essa busca, todos reconhecem a imagem em questão como um mero emblema; ela só serve como ocasião para que o escândalo se manifeste [ver Koch]. Se não fosse pelo conflito, todos, nos dois lados, folgariam em confessar que não é o objeto que está em disputa; que ele é só um marco para algo completamente diferente. ${ }^{19}$ Então para os Cs, a imagem em si não está de modo algum em questão, eles não têm nada contra ela (como os As têm) ou a favor dela (o caso dos Bs). A imagem simplesmente não tem valor - sem valor, mas atacada, e por isso defendida, e por isso atacada...

O que é terrível para os destruidores de ídolos é que não há jeito de decidir com certeza se eles são As, Bs, ou Cs. Talvez eles tenham se equivocado quanto à sua vocação; talvez eles estejam interpretando mal os gritos de horror daqueles que chamam de filistinos, quando estes vêem seus ídolos reduzidos a pó. Eles se vêem como profetas, mas talvez sejam meros "agentes provocadores”. Eles se vêem libertando as pobres almas miseráveis aprisionadas por coisas monstruosas; mas e se eles fossem, ao contrário, difamadores à procura de maneiras de humilhar mais eficientemente seus opositores?

O que aconteceria comigo se, ao criticar os críticos, eu próprio estivesse simplesmente tentando criar outro escândalo? E se o iconoclash, na sua pretensão de redescrever o iconoclasmo, não fosse nada mais que outro gesto iconoclástico tedioso, outra provocação, a mera repetição do trejeito sem fim dos tesouros mais queridos da intelligentsia? Não sabemos ao certo.

Ah, mas é por isso que se chama iconoclash.

\section{As pessoas "D" estão quebrando imagens inadvertidamente}

Há outro tipo de destruidor de ícones, presente nesta exposição - um caso muito desviante: o daqueles que poderiam ser chamados de "vândalos inocentes”. Como é bem sabido, vandalismo é um termo de insulto inventado para descre-

\footnotetext{
${ }^{18} \mathrm{O}$ politicamente correto é parte dessa atitude: patrulhar todos os lugares procurando por boas ocasiões para ficar escandalizado.

${ }^{19}$ Sobre o mecanismo de difusão de escândalos na arte contemporânea, ver Heinich Gamboni (1996 e neste catálogo). Para “casos” sociais e políticos, ver Luc Boltanski (1990). O mecanismo típico para ver objetos como emblemas foi proposto por René Girard (1987).
}

Horizontes Antropológicos, Porto Alegre, ano 14, n. 29, p. 111-150, jan./jun. 2008 
ver aqueles que destroem não tanto pelo ódio às imagens, mas por ignorância, por desejo de lucro e pura paixão e insanidade (Chastel, 1983; Réau, 1994).

Claro, o rótulo pode ser usado para descrever a ação dos As, dos Bs e também dos Cs. Todos podem ser acusados de vandalismo pelos outros, que não sabem se eles são crédulos inocentes furiosos por terem sido acusados de ingenuidade, se são filisteus despertados de seu sono dogmático por chamados proféticos, ou amantes de escândalos, deliciados por serem a vítima da crítica e, assim, capazes de demonstrar a força e a retidão de sua indignação.

Mas os vândalos inocentes são diferentes dos vândalos normais, os “maus": eles não tinham absolutamente a mínima idéia de que estavam destruindo alguma coisa. Ao contrário, eles estavam adorando imagens e protegendo-as da destruição, e mesmo assim são acusados de tê-las profanado e destruído! ${ }^{20}$ Eles são, por assim dizer, iconoclastas em retrospecto. O exemplo típico é o dos restauradores, acusados por alguns de "matar com ternura” [ver Lowe]. O campo da arquitetura, em especial, está repleto desses "inocentes" que, quando constroem, têm que destruir, e seus prédios são acusados de não serem nada mais que vandalismo [ver Obrist, Geimer]. Seu coração está cheio de amor pelas imagens - portanto, eles são diferentes de todos os outros casos mas ainda assim eles despertam as mesmas imprecações de "profanação", "sacrilégio" e "blasfêmia", como todos os outros.

A vida é dura: ao restaurar as obras de arte, embelezar cidades, reconstruir sítios arqueológicos, eles os destruíram - dizem seus oponentes - a ponto de parecerem os piores iconoclastas, ou ao menos os mais perversos. Mas outros exemplos podem ser encontrados, como o daqueles curadores de museu que guardam os lindos mallagans da Nova Guiné, apesar de estes não terem mais valor, já que, aos olhos daqueles que os fabricaram, eles deveriam ser destruídos em três dias... [ver Derlon, Sarrô], ou que guardam aqueles objetos africanos que foram cuidadosamente feitos para apodrecer no chão e que são cuidadosamente salvos por negociantes de arte e assim privados de seu poder, aos olhos de seus fabricantes [ver Strother]. ${ }^{21} \mathrm{O}$ feiticeiro aprendiz não é real-

\footnotetext{
${ }^{20}$ A censura pode ser um aspecto dos Ds: destruindo ou escondendo imagens para proteger outras imagens e escolhendo o alvo errado. Cineastas estão ocupados deletando imagens do World Trade Center de seus filmes para não chocar o público (International Herald Tribune, 25 de outubro de 2001).

${ }^{21}$ Outros casos podem ser encontrados de destruição retrospectiva na tecnologia: asbesto costumava ser o "material mágico" antes de seus produtores serem acusados de matar milhares de pessoas com ele; DDT costumava ser o pesticida mágico antes de ser acusado dos mesmos crimes. Ver Ulrich Beck (1995), para um relato desta acusação retrospectiva sobre a noção de "efeito secundário”.
}

Horizontes Antropológicos, Porto Alegre, ano 14, n. 29, p. 111-150, jan./jun. 2008 
mente um feiticeiro do mal, mas alguém que se torna do mal por causa de sua própria inocência, ignorância e negligência.

E aqui, novamente, os As assim como os Bs e os Cs podem ser acusados de serem Ds, ou seja, de mirar no alvo errado, de esquecer de levar em consideração os efeitos colaterais, as últimas conseqüências de seus atos de destruição. "Você acreditava salvar as pessoas da idolatria, mas você simplesmente os privou dos meios para cultuar". "Você acredita ser um profeta renovando o culto das imagens com imagens mais frescas, mas você nada mais é que um difamador sedento de sangue” - estas e outras acusações similares freqüentemente se nivelam em círculos revolucionários, em mútuas acusações de que o outro está constantemente no passo errado, de que é - horresco referens - reacionário. E se o que fizemos foi matar as pessoas erradas, destruir os ídolos errados? Pior: e se assim sacrificamos ídolos para o culto de um Baal maior, mais sangrento e mais monstruoso?

\section{As pessoas "E" são simplesmente as pessoas: eles ridicularizam os iconoclastas e os iconófilos}

Para completar, devemos adicionar os Es, que duvidam dos quebradores de ídolos tanto quanto dos cultuadores de ícones. Eles desconfiam de quaisquer distinções marcadas entre os dois pólos; eles exercem sua ironia devastadora contra todos os mediadores; não que queiram livrar-se destes, mas porque estão muito conscientes de sua fragilidade. Eles adoram manifestar irreverência e falta de respeito, eles querem gozação e zombaria, eles exigem direito absoluto à blasfêmia e o fazem de um modo feroz, rabelaisiano [ver Pinchard], eles mostram a necessidade da insolência, a importância do que os romanos chamavam "pasquinadas" - tão necessárias para um senso saudável de liberdade civil -, a dose indispensável do que Peter Sloterdijk chamou kinicismo [kynicism] (em oposição ao cinismo [cynicism] tipicamente iconoclasta).

Existe um direito de não acreditar e outro, ainda mais importante, de não ser acusado de acreditar ingenuamente em algo. Talvez não exista isso a que chamamos um crédulo. Com exceção do raro destruidor de ícones que acredita na crença - e que, estranhamente, acredita em si próprio como o único nãocrédulo. Esse agnosticismo saudável, amplo, popular e indestrutível pode ser a fonte de muita confusão porque, aqui também, as reações que os Es desencadeiam são indistinguíveis daquelas criadas pelos atos de destruição-regenera- 
ção dos As, Bs, Cs e Ds. É tão fácil ficar chocado. Todo mundo tem uma quantidade de "chocabilidade" que pode certamente ser aplicada a diferentes causas, mas de maneira alguma esvaziada ou mesmo diminuída.

Tome-se o ícone, agora famoso, do papa João Paulo II caído ao chão, atingido por um meteorito [ver Maurizio Cattelan, La Nona Hora]. Será que ele demonstra uma irreverência saudável pela autoridade? Será que é um caso típico de provocação barata, dirigida a londrinos blasés que esperam ficar moderadamente chocados quando vão a uma mostra de arte, mas que não dão a mínima em relação à morte de uma imagem maçante como a do papa? Ou é, ao contrário, uma tentativa escandalosa de destroçar a crença dos visitantes de museu poloneses, quando a obra for mostrada em Varsóvia? Ou é, como Christian Boltanski afirma, uma imagem profundamente respeitosa, que mostra que, no catolicismo, demanda-se do papa sofrer a mesma quebra, a mesma destruição extrema que o próprio Cristo ${ }^{22}$ Como é possível examinar essa amplitude de interpretações? ${ }^{23}$

Daí a paisagem sonora desta exposição.

\section{Uma cacofonia bem-vinda}

Nossa mostra almeja escutar aqueles gritos de desespero, horror, indignação e estupefação - simultaneamente, todos ao mesmo tempo, sem ter de escolher apressadamente, sem ter de cerrar fileiras nos partidos e sair brandindo algum martelo para completar algum ato de desconstrução. Daí a cacofonia, que é o equivalente auditivo dos iconoclashes e que ocupa tanto espaço nesta exposição [ver Laborde].

\footnotetext{
${ }^{22}$ Christian Boltanski, comunicação verbal.

${ }^{23} \mathrm{Eu}$ propus um teste a um catalão: substituir o papa, que todos (talvez não os poloneses) esperam ver esmagado no chão, por alguém cuja destruição provocaria a indignação dos intelectuais: por exemplo, mostrar Salman Rushdie morto por um tiro islâmico... Horrível demais, escandaloso demais, me disseram (Obrist, comunicação verbal). Ahá! Então o papa pode ser atingido, mas não alguém realmente merecedor de respeito aos olhos dos que pensam criticamente! Mas quando propus o que parecia ser um sacrilégio verdadeiro e não banal, o que eu buscava? Outra provocação dirigida a fiéis críticos ao invés de fiéis papistas? Quem pode dizer? Não tenho nem certeza se entendo as reações daqueles que se encolheram de horror ante minha sugestão.
}

Horizontes Antropológicos, Porto Alegre, ano 14, n. 29, p. 111-150, jan./jun. 2008 
Por meio do som tanto quanto da imagem, queremos restaurar esse senso de ambigüidade: quem está gritando contra a destruição, e por quê? Serão esses os lamentos dos eternos filisteus, chocados por serem tirados de seu tedioso e estreito círculo de costumes? Ouçam, ouçam! Serão esses os lamentos de humildes devotos, privados de sua única fonte de virtude e vinculação, as relíquias sagradas, os fetiches preciosos, os frágeis factiches que costumavam mantê-los vivos e estão agora quebrados por um reformador arrogante e cego? (Nathan, 1994). Ouçam, ouçam! O som dos soluços dos As ao se darem conta de que nunca irão alcançar a violência gentil dos proféticos Bs, e que eles simplesmente esvaziaram o mundo e o tornaram ainda mais aterrador. Ouçam novamente, por trás dos lamentos cacofônicos, a risada sarcástica dos blasfemos Es, tão saudáveis, tão felizes por dispor e exibir seu charivari juvenil. E por trás disso tudo, o que é isso? esse outro som? Ouçam, ouçam! a trombeta profética despertando-nos de nossa vinculação mortal para ressuscitar um novo senso de beleza, verdade e santidade das imagens. Mas quem faz esse ruído horrível, estridente? Ouçam, ouçam! Que estardalhaço, o som estridente dos provocadores, procurando uma nova presa.

Sim, um pandemônio: nosso mundo diário.

\section{Para além das guerras de imagens: cascatas de imagens}

Como podemos ter certeza de que nossa mostra não é outra mostra iconoclasta? Ter certeza de que não estamos pedindo ao visitante e ao leitor para descer mais uma espiral no inferno do desmascaramento e da crítica? Que não estamos adicionando outra camada de ironia, empilhando descrença sobre descrença, continuando a tarefa de desencantamento com ainda mais desencantamento? Novamente, não há nenhuma concordância entre os curadores; seja como for, um consenso não é nosso objetivo, já que estamos atrás de iconoclashes, não de certezas. E ainda assim nossa exposição afirma ser capaz de ir além das guerras de imagens. É sempre uma afirmação audaciosa, essa pequena palavra: além. Como podemos ser fiéis a ela?

Apresentando imagens, objetos, estátuas, signos e documentos, de um modo que demonstre as conexões que eles têm com outras imagens, objetos, estátuas, signos e documentos. Em outras palavras, estamos tentando afirmar que pertencemos ao grupo dos Bs contra os As, os Cs, os Ds e mesmo os Es. Sim, nós pretendemos ser da linhagem profética! As imagens contam, sim; elas não são meros emblemas, e não por serem os protótipos de algo longe, acima, 
abaixo; elas contam porque permitem que se passe para outra imagem, precisamente tão frágil e modesta quanto a anterior - mas diferente. ${ }^{24}$

Assim, a distinção crucial que desejamos traçar nesta mostra não é entre um mundo de imagem e um mundo de não-imagem - como os combatentes da guerra das imagens queriam que acreditássemos - mas entre o fluxo interrompido de figuras e uma cascata delas. Ao dirigir a atenção dos visitantes para as cascatas, não esperamos paz - a história da imagem está por demais carregada -; mas estamos gentilmente dando uma cutucada para que o público procure outras propriedades da imagem, propriedades que as guerras religiosas esconderam completamente na poeira levantada em seus muitos incêndios e injúrias.

\section{A opacidade dos ícones religiosos}

Tome-se, por exemplo, esta pequena e humilde Pietá, vinda do Museu de Moulins, na França. Protestantes ou, posteriormente, fanáticos revolucionários (ou talvez vândalos) decapitaram a Virgem e quebraram as pernas do Cristo morto - embora as escrituras digam que nenhum de seus ossos será quebrado. Um pequeno anjo, intacto, invisível na imagem, segura com pesar a cabeça descaída do Salvador. Um gesto iconoclasta, com certeza. Mas, espere! O que é um Cristo morto senão outro ícone quebrado, a imagem perfeita de Deus, dessacralizada, crucificada, perfurada e pronta para ser colocada na tumba? Então o gesto iconoclasta golpeou uma imagem que já havia sido quebrada [ver Koerner]. O que significa crucificar um ícone crucificado?

Não nos defrontamos aqui com um bom iconoclash? O quebrador de ídolos foi redundante, já que ele (por alguma razão obscura, continuo mantendo o masculino para tal tipo de feito) despedaçou um ícone que já fora quebrado. Mas há uma diferença entre os dois gestos: o primeiro era uma meditação profunda e antiga sobre a fraqueza de todos os ícones; o segundo apenas adicionou uma espécie de vontade simplória de se livrar de todos os ídolos, como se houvesse ídolos e cultuadores de ídolos! Os que combatem as imagens sempre

\footnotetext{
${ }^{24}$ No seu ótimo resumo visual de imagens e seu protótipo, Jean Wirth (2001) manifesta uma vez mais a contradição do argumento, já que para mostrar a diferença entre respeito pela imagem (dulia) e adoração do modelo (latria), ele é forçado, por necessidade, a desenhar duas imagens - uma para o protótipo e outra para o original.
}

Horizontes Antropológicos, Porto Alegre, ano 14, n. 29, p. 111-150, jan./jun. 2008 
cometem o mesmo erro: eles ingenuamente acreditam em crença ingênua. O destruidor de ídolos só fez demonstrar sua ingenuidade ao imaginar que o primeiro destruidor era um cultuador de ídolos, quando na verdade ele (ou ela) deve ter sido um ótimo destruidor de ícones... Nessa tradição, a imagem é sempre aquela de uma brecha para tornar o objeto impróprio para o consumo normal [ver Mondzain, Stoddard]. ${ }^{25}$

Como Louis Marin argumentou em um belo livro, o mesmo é verdade em relação a pinturas religiosas cristãs, que não tentam mostrar nada - ao contrário, tentam obscurecer a visão (Marin, 1989). Milhares de pequenas invenções forçam o espectador, o devoto, a não ver o que está apresentado diante dele ou dela. Mas não, como os defensores de ícones freqüentemente dizem, fazendo a atenção afastar-se da imagem e direcioná-la ao protótipo. Não há protótipo para ser olhado - isso seria um platonismo enlouquecido -; há somente o redirecionamento da atenção para outra imagem.

Os peregrinos de Emaús não vêem nada no seu companheiro de viagem, tal como foi pintado por Caravaggio, mas a partilha do pão revela o que eles deveriam ter visto, o que o espectador só consegue ver através da luz suave que o pintor acrescentou ao pão. Mas não é nada além de uma pintura. Redirecionar a atenção é sempre a tarefa que essas pinturas tentam realizar, forçando assim o fiel a passar de uma imagem para a próxima. "Ele ressurgiu, já não está aqui; eis o lugar onde o depositaram” (Marcos, 16:6).

Quão equivocadas estavam as guerras das imagens: não há sequer uma figura que já não esteja quebrada ao meio. Todo ícone repete: noli me tangere, e eles são acusados por seus inimigos de atraírem muita atenção! Vamos mesmo gastar mais um século a ingenuamente redestruir e desconstruir imagens que já foram tão sutil e inteligentemente destruídas?

\section{Isolada, uma imagem científica não tem referente}

A cascata de imagens é ainda mais impressionante quando se olha para a série reunida sob o rótulo de ciência. ${ }^{26}$ Uma imagem científica isolada não tem

\footnotetext{
${ }^{25}$ Ver o lindo capítulo de Joseph Koerner (1998) sobre Bosh; ver a noção de “dissimiles” em Georges Didi-Huberman (1990).

${ }^{26}$ A palavra “cascata” para descrever essa sucessão foi primeiramente usada por Trevor Pinch (1985), Mike Lynch e Steve Woolgar (1990) e Jones e Galison (1998).
} 
significado algum, não prova coisa alguma, não diz nada, não mostra nada, não tem referente. Por quê? Porque uma imagem científica, até mais do que uma imagem religiosa cristã, é um conjunto de instruções para alcançar outra mais além. ${ }^{27}$ Uma tabela de números leva a um gráfico que leva a uma fotografia que irá levar a um diagrama que irá levar a um parágrafo que irá levar a uma afirmação. A série como um todo tem um significado, mas nenhum de seus elementos tem qualquer sentido.

Nos belos exemplos sobre a astronomia, apresentados por Galison, não se pode parar em nenhum ponto da série, se se quiser "entender" o fenômeno que elas representam. Mas se você percorrer a série inteira, de cima a baixo, então objetividade, visibilidade e veracidade irão surgir. O mesmo vale com relação ao exemplo da biologia molecular, oferecido por Rheinberger: na radio labelling ${ }^{28}$ não há nada para ver em estágio algum, e no entanto não há outro jeito de se ver os genes. A invisibilidade na ciência é ainda mais notável do que na religião - por isso, nada é mais absurdo que a oposição entre o mundo visível da ciência e o mundo “invisível” da religião [ver Huber, Macho]. Nenhum deles pode ser compreendido a não ser por meio de imagens quebradas de tal modo que sempre apontam para mais uma outra.

Se você quisesse abandonar a imagem e, no lugar dela, voltar o olhar para o protótipo, do qual elas são supostamente a imagem, você veria menos, infinitamente menos. ${ }^{29}$ Você ficaria cego de vez. Peça a uma cientista, uma física, que pare de olhar para as inscrições produzidas pelos seus detectores, e ela não vai encontrar nada: ela só vai começar a ter uma mínima idéia a respeito se reunir ainda mais inscrições, ainda mais resultados instrumentais, ainda mais equações (Galison, 1997). É somente lá dentro das paredes da sua torre de marfim que ela ganha acesso ao mundo "lá fora".

Esse paradoxo das imagens científicas é de novo inteiramente perdido por aqueles que combatem as imagens; eles nos pediriam com violência para escolher entre o visível e o invisível, a imagem e o protótipo, o mundo real lá fora e o mundo inventado e artificial aqui dentro. Eles não conseguem entender que

\footnotetext{
${ }^{27}$ Para uma descrição desse efeito cascata, ver Bruno Latour (1999, cap. 2).

${ }^{28} \mathrm{O}$ método de identificação ou triagem radioativa de partículas biológicas, radio labelling, tem sido traduzido para o português como "marcação radioativa”. (N. de E.).

${ }^{29}$ Por isso demorou tanto para o olhar científico acomodar sua vista às estranhas novas imagens científicas como é magnificamente demonstrado em Lorraine Daston e Katherine Park (1999).
}

Horizontes Antropológicos, Porto Alegre, ano 14, n. 29, p. 111-150, jan./jun. 2008 
quanto mais artificiosa a inscrição, maior a sua habilidade de se conectar, de se aliar a outras, de gerar uma objetividade ainda melhor.

Assim, pedir aos destruidores de ídolos que despedacem os muitos mediadores da ciência para atingir o mundo real lá fora, melhor e mais rápido, seria uma chamada à barbárie, não à iluminação. Nós realmente teremos que passar mais um século alternando violentamente entre construtivismo e realismo, entre artificialidade e autenticidade? A ciência merece algo melhor do que culto ingênuo e desdém ingênuo. Seu regime de invisibilidade tem tanta elevação quanto o da religião e da arte. A sutileza de seus traços requer uma nova forma de cuidado e atenção. Ela requer - por que evitar a palavra? -, sim, espiritualidade.

\section{A arte não é para ser redimida}

Conectar imagens com imagens, brincar com séries delas, repeti-las, reproduzi-las, distorcê-las levemente, tem sido uma prática comum na arte mesmo antes da infame "era da reprodução mecânica”. "Intertextualidade” é um dos modos pelos quais a cascata de imagens é discernível no domínio artístico - a firme e intricada conexão que cada imagem tem com todas as outras que foram produzidas, a complexa relação de seqüestro, alusão, destruição, distância, citação, paródia e disputa [ver Jones, Belting, Weibel]. Mesmo a conexão mais simples é tão importante para uma definição de uma vanguarda que, uma vez que um tipo de imagem foi concebido, não é mais possível para outros produzi-la da mesma forma.

Mas há uma relação mais direta: de muitas maneiras, através da questão da representação mimética, as artes ocidentais têm sido obcecadas pelas sombras colocadas pelas imagens científicas e religiosas: como escapar da obrigação de mais uma vez apresentar os credos dos fiéis? Como escapar da tirania das ilustrações quase-científicas, "simplesmente objetivas”, "puramente representativas”? Libertar o olhar dessa obrigação dual explica em grande parte as invenções do que é chamado de arte moderna. E, claro, os críticos "reacionários" nunca se cansam de pedir por um "retorno" à "real presença”, à "representação correta", à "mimese" e ao culto à beleza, como se posse possível fazer o relógio andar para trás (Clair, 1983; Steiner, 1991). ${ }^{30}$

\footnotetext{
${ }^{30}$ Para um arquivo sobre o debate em torno da arte contemporânea, ver P. Barrer (2000).
} 
Eis então outro paradoxo, outro iconoclash: o que é isso de que a arte contemporânea tanto se esforçou por escapar? A que alvo foi direcionado tanto iconoclasmo, tanto ascetismo, tão violenta e, por vezes, frenética energia? Aos ícones religiosos e sua obsessão por presença real? Mas eles nunca tiveram algo a ver com a apresentação de outra coisa que não a ausência. Ao imaginário científico? Mas nenhuma imagem científica isolada tem qualquer poder mimético; não há nada menos representacional, menos figurativo, que as figuras produzidas pela ciência, as quais são, apesar disso, tidas como o que nos dá a melhor apreensão do mundo visível (Elkins, 1999). ${ }^{31}$

Aqui, novamente, temos outro caso de guerras de imagem dirigindo nossa atenção para um alvo completamente falso. Muitos artistas tentaram evitar a carga pesada da presença e da mimese evitando religião e ciência, as quais tentaram ainda mais intensamente evitar presença, transparência e mimese! Uma comédia de erros.

Por quanto tempo iremos julgar uma imagem, instalação ou um objeto com base nas outras imagens, instalações e objetos que este almeja combater, substituir, destruir, ridicularizar, classificar, parodiar? Será que é tão essencial para a arte que um longo séquito de escravos e vítimas acompanhe cada obra? A distorção de uma imagem já existente é mesmo o único jogo disponível por aí?

Felizmente, existem muitas outras formas de arte, muitos outros tipos de instalações, dispositivos de toda sorte, que de maneira alguma se apóiam nessa conexão negativa entre imagem e distorção. Não que eles se apóiem na mimese, o que restringiria o olhar ao tipo mais entediante de costume visual; mas porque aquilo de que eles mais gostam é a transformação das imagens; a cadeia de modificações que altera completamente os regimes escópicos da clássica imagem congelada, extraída do fluxo [ver Lowe, Yaneva, Jaffrennou].

Essa diferença entre a distorção iconoclasta, que sempre se apóia no poder do que é destruído, e uma cascata produtiva de re-representação pode explicar por que, nesta exposição, a definição de arte dada por Peter Weibel, por exemplo, não se cruza de modo algum com a de alguém como Adam Lowe - eis outro iconoclash, e, espera-se, bastante fecundo visualmente.

\footnotetext{
${ }^{31}$ Pode-se até argumentar que é de olhar pinturas (provavelmente pinturas holandesas) que os filósofos da ciência tiraram suas idéias do mundo visível e sua epistemologia modelo/cópia. Ver o clássico Svetlana Alpers (1983).
} 


\section{Depois do 11 de setembro}

Como Christin, Colas, Gamboni, Asmann e muitos outros mostraram, sempre houve uma conexão direta entre o status da imagem e a política. Destruir imagens sempre foi uma ação cuidadosamente planejada, governada e elitista. Nada menos popular, espontâneo e não-dirigido que a destruição de ídolos. Embora a palavra representação apareça ainda mais vividamente na esfera pública do que na ciência, na religião e na arte, nós não tratamos o iconoclasmo na política como um domínio separado.

Há uma razão simples para isso: para rejuvenescer a definição de mediadores políticos é essencial, primeiro, ir além das guerras de imagem. A política está por todo lado, na mostra, mas intencionalmente espalhada. O iconoclasmo se tornou muito banal quando aplicado na esfera política. Em nenhum outro lugar, mais do que na política, pode-se ouvir esta requisição absurda, porém estridente: “É manipulado ou é real?” É como se, novamente, o trabalho manual, a manipulação cuidadosa, a mediação humana, devessem ser colocados em uma coluna, e a verdade, a exatidão, a mimese, a representação fiel, em outra. Como se tudo o que fosse adicionado como crédito em uma coluna tivesse de ser deduzido da outra. Contabilidade estranha! - isso faria a política, assim como a religião, a ciência, a arte, totalmente impossíveis. Mais um caso de aplicação impossível do segundo mandamento.

Mas a devoção à destruição da imagem, o culto do iconoclasmo como a máxima virtude intelectual, a mente crítica, o gosto pelo niilismo - tudo aquilo deve ter mudado abruptamente devido a um evento terrível, estranhamente codificado pelo número 911 - o número telefônico de emergência nos Estados Unidos. Sim, desde 11 de setembro de 2001 um estado de emergência foi proclamado, relativo ao modo como lidamos com imagens de todos os tipos, em religião, política, ciência, arte e crítica - e uma busca frenética pelas origens do fanatismo começou.

O niilismo - entendido aqui como a negação de mediadores, o esquecimento da mão que trabalha no despertar dos objetos transcendentes, o corte modernista entre o que se faz e o que se pensa que o outro está fazendo poderia aparecer como uma virtude, uma qualidade robusta, uma fonte formidável de inovação e força, desde que nós pudéssemos aplicá-la aos outros de verdade e a nós mesmos apenas simbolicamente. Mas agora, pela primeira vez, são os EUA, somos nós, os ocidentais, os corajosos quebradores de 
ídolos, os guerreiros da liberdade, que somos ameaçados pela aniquilação e pelo fanatismo.

Da mesma maneira que os roteiristas de Hollywood estão de repente achando insuportáveis os efeitos especiais dos filmes de horror que eles mesmos prepararam, porque suas realidades são vívidas demais e só eram suportáveis quando não poderiam acontecer, nós podemos achar que a fala ininterrupta sobre destruição, desmascaramento, crítica, exposição e denúncia não é, afinal, tão divertida, tão produtiva, tão protetora.

Nós sabíamos (eu sabia!) que jamais fomos modernos, mas agora o somos menos ainda: frágeis, fracos, ameaçados; ou seja, de volta ao normal, de volta ao estágio ansioso e cuidadoso no qual os "outros" costumavam viver antes de serem "libertados" de suas "crenças absurdas” pela nossa corajosa e ambiciosa modernização. De repente, parecemos apegar-nos com nova intensidade aos nosso ídolos, nossos fetiches, nossos factiches, aos modos extraordinariamente frágeis com que nossa mão pode produzir objetos sobre os quais não temos nenhum comando. De certo modo, vemos as nossas instituições, nossas esferas públicas, nossa objetividade científica, mesmo nossas maneiras religiosas - tudo que antes amávamos odiar - com uma simpatia renovada. Menos cinismo, de repente; menos ironia. Uma devoção às imagens, um desejo por mediadores cuidadosamente construídos, aquilo que os bizantinos chamavam de "economia", o que costumava simplesmente ser chamado de civilização.

Nenhuma exposição, nenhum catálogo, pode fazer muito. Sei disso muito bem, mas redirecionar a atenção para a fraqueza e a fragilidade dos mediadores que nos permitem rezar, conhecer, votar, desfrutar de uma vida em comum, isto é o que tentamos em Iconoclash. Agora, leitores e visitantes, é com vocês: ver por si próprios o que querem proteger e o que querem destruir.

Ah, e a propósito: como Moisés redigiria o segundo mandamento se não o tivesse interpretado mal? É um pouco cedo para saber, nós precisamos primeiro ouvir e ver as reações de vocês, mas minha aposta é que uma leitura segura seria: "Não congelarás nenhuma imagem gravada”.

\section{Anexo 1 - Abraão e a oficina de ídolos de seu pai Terah}

"Rabi Hiya, filho do rabi Ada, disse que Terah [pai de Abraão] era um adorador de ídolos. Um dia Terah teve de sair da loja [em que vendia ídolos]. Ele pôs Abraão para cuidar da loja na sua ausência. Um homem veio e queria 
comprar um ídolo. Abraão perguntou-lhe: ‘Quantos anos você tem?’ E ele respondeu: 'Cinqüenta ou sessenta anos.' Abraão então falou, 'Digno de pena é o homem de sessenta anos que cultua ídolos que só têm um dia de idade.' Então o homem saiu envergonhado. Uma vez, veio uma mulher com uma oferenda de ótima farinha. Ela disse a ele [Abraão]: 'Eis aqui, pegue-a e traga-a perante [os ídolos].’ Abraão levantou-se, pegou um cajado, quebrou todos os ídolos, e colocou o cajado de volta nas mãos do maior ídolo entre eles. Quando seu pai retornou, indagou: 'Quem fez isso a eles?’ Abraão respondeu: ‘Eu não lhe negarei a verdade. Uma mulher veio com uma oferenda de ótima farinha e pediu que eu a trouxesse diante deles. Então eu a trouxe diante eles, e cada um disse: 'Eu comerei primeiro.' Então o maior de todos levantou-se, tomou o cajado em suas mãos e quebrou todos os outros.' E Terah disse a ele: 'Por que você zomba de mim? Estes [ídolos] sabem alguma coisa [falar e mover-se]?’ E Abraão respondeu: 'Seus ouvidos não escutam o que sua boca fala?'”

Midrash Rabbah, Noé, Parte 38, Seção 13

Traduzido para o inglês por Shai Lavi

\section{Anexo 2 - Jagannath e seu salagrama}

O trecho a seguir, de uma novela da escritora indiana Anantha Murthy, está na origem desta mostra. É uma rara descrição do íntimo de um iconoclasta. Jagannath, ${ }^{32}$ o personagem principal, é um brâmane que retorna da Inglaterra decidido a libertar os intocáveis do controle que ele e seu "salagrama” (a pedra sagrada de seus ancestrais) tem sobre eles:

"As palavras ficaram presas em sua garganta. Esta pedra é nada, mas coloquei nela meu coração e estou estendendo a mão para entregá-la a você: toque-a; toque o ponto vulnerável da minha mente; esta é a hora da prece noturna; toque; o nandadeepa ainda está queimando. Aqueles de pé atrás de mim [sua tia e o sacerdote] estão me puxando de volta pelos muitos laços de

\footnotetext{
${ }^{32}$ Não sem um pouco de ironia, o herói tem o nome de “Jagannath”, ou “Senhor do Mundo”, que é também o nome da pesada carruagem de Krishna debaixo da qual diz-se que os devotos se jogam para morrer. Isto nos deu, em inglês, “juggernaut”, para designar uma força poderosamente esmagadora. Outro iconoclash.
} 
obrigação. O que vocês estão esperando? O que eu trouxe? Talvez seja assim: isto se tornou um salagrama porque eu o ofereci como pedra. Se você tocá-lo, então ele seria uma pedra para eles. Esta minha impertinência se torna um salagrama. Porque eu o dei, porque vocês o tocaram, e porque eles todos testemunharam esse evento, deixem esta pedra virar um salagrama, neste anoitecer. E deixem o salagrama virar uma pedra.” (101)

Mas os párias se encolhem em horror.

“Jagannath tentou acalmá-los. Ele disse, em seu tom cotidiano de professor: 'Isto é mera pedra. Toquem-na e verão. Se não o fizerem, permanecerão tolos para sempre.'

"Ele não sabia o que lhes havia acontecido, mas viu que o grupo inteiro de repente se encolhia. Eles contraíram os rostos em expressão desconfiada, temerosos de ficar e temerosos de sair dali. Ele havia desejado e ansiado por este momento auspicioso - este momento dos párias tocando a imagem de Deus. Ele falou com voz embargada de grande fúria: 'Sim, toquem-na!'

“Avançou na direção deles. Eles recuaram, encolhidos. Alguma crueldade monstruosa tomou conta do homem que havia nele. Os párias pareciam criaturas repulsivas, rastejando sobre suas barrigas.

"Ele mordeu o lábio inferior e disse em voz baixa e firme: 'Pilla, toque-a! Sim, toque-a!'

"Pilla [um capataz da casta dos intocáveis] ficou parado, piscando os olhos. Jagannath sentiu-se exausto e perdido. Tudo que lhes havia ensinado durante todos esses dias fora um desperdício. Ele chacoalhou de modo amedrontador: 'Toquem, toquem, vocês TOQUEM-NA!'

"Era como o som de algum animal enfurecido e veio rasgando através dele. Ele era pura violência; ele não tinha consciência de nada mais. Os párias acharam-no mais ameaçador que Bhutaraya [o espírito-demônio do deus local]. $\mathrm{O}$ ar fora fendido pelos seus gritos. ‘Toquem, toquem, toquem.’ A tensão era demais para os párias. Mecanicamente, eles avançavam, apenas tocavam o que Jagannath lhes estendia, e imediatamente se retiravam.

"Exausto pela violência e a opressão, Jagannath atirou de lado o salagrama. Uma crescente angústia chegara a um fim grotesco. A tia conseguia ser humana mesmo ao tratar os párias como intocáveis. Ele por um momento perdera sua humanidade. Os párias tinham sido para ele coisas insignificantes. Ele baixou a cabeça. Não sabia quando os párias haviam partido. A escuridão já baixara quando ele se deu conta de que estava só. Desgostoso com sua própria pessoa, começou a andar a esmo. Perguntou a si mesmo: quando eles a toca- 
ram, nós - eles e eu - perdemos nossa humanidade, não foi? E nós morremos. Onde está a falha, em mim ou na sociedade? Não houve resposta. Depois de uma longa caminhada ele veio para casa, sentindo-se perturbado.” (98-102)

Anantha Murthy, Bharathipura, Madras (Índia), Macmillan, 1996.

Traduzido do Kannada original.

\section{Referências}

ALPERS, Svetlana. The art of describing. Chicago: University of Chicago Press, 1983.

ASSMANN. Jan. Moses the Egyptian: the memory of Egypt in Western monotheism. Cambridge: Harvard University Press, 1997.

ASSMANN, Jan. Moise l'egyptien: un essai d'histoire de la mémoire. Paris: Aubier, 2001.

BARRER, P. (Tout) l'art contemporain est-il nul?: le débat sur l'art contemporain em France avec ceux qui l'ont lance: bilan et perspective. Lausanne: Favre, 2000.

BECK, Ulrich. Ecological politics in an Age of Risk. Cambridge: Polity Press, 1995.

BOLTANSKI, Luc. L'amour et la justice comme compétences. Paris: A.-M. Métailié, 1990.

CENTILIVRES, Pierre. Les Boudhas d'Afghanistan. Lausanne: Favre, 2001. CHASTEL, André. The sac of Rome - 1527. Princeton: Princeton University Press, 1983.

CLAIR, Jean. Considérations sus l'état des beaux arts: citique de la modernité. Paris: Gallimard, 1983.

CLARK, Tim J. Farewell to an idea: episodes from a History of Modernism. New Haven: Yale University Press, 1999. 
CLÉMENT, Jean-François. L'image dans le monde arabe: interdits et possibillités. In: BEAUGÉ, G.; CLÉMENT, J.-F. (Ed.). L'image dans le monde arabe. Paris: CNRS, 1995. p. 11-42.

COLAS, Dominique. Le glaive et le fléau: généalogie du fanatisme et de la société civile. Paris: Grasset, 1992.

DASTON, Lorraine; GALISON, Peter. The image of objectivity. Representation, v. 40, p. 81-128, 2001.

ELKINS, James. Why are our pictures puzzles? London: Routledge, 1999.

FREUD, Sigmund. L'homme Moïse et la religion monothéiste: trois essays. Paris: Gallimard, 1996.

GALISON, Peter. Image and logic: a material culture of microphysics. Chicago: The University of Chicago Press, 1997.

GALISON, Peter. Judgment against objectivity. In: JONES, Caroline A.; GALISON, Peter (Ed.). Picturing science, producing art. New York: Routledge, 1998. p. 327-359.

GAMBONI, Heinich. The destruction of art: iconoclasm and vandalism since the French Revolution. London: Reaktion Books, 1996.

GIRARD, René. Things hidden since the foundation of the world. Stanford: Stanford University Press, 1987.

HACKING, Ian. The social construction of what? Cambridge: Harvard University Press, 1999.

DASTON, Lorraine; PARK, Katherine. Wonders and the Order of Nature. Cambridge: Zone Books, 1999.

DIDI-HUBERMAN, Georges. Fra Angelico: dissemblance et figuration. Paris: Flammarion, 1990.

DUPEUX, Cécile et al. (Ed.). Iconoclasme: vie et mort de l’image médiévale. Paris: Somogy Éditions d'art, 2001.

GROYS, Boris. Staline, oeuvre d'art totale. Paris: Jacqueline Chambon, 1990. 
GRUZINSKI, Serge. La colonisation de l'imaginaire: sociétés indigénes et occidentalisation dans le mexique espagnol XVI XVIII. Paris: Gallimard, 1988.

KOERNER, Joseph. Hieronymus Bosch's world picture. In: JONES, Caroline A.; GALISON, Peter (Ed.). Picturing science, producing art. New York: Routledge, 1998. p. 297-324.

LATOUR, Bruno. Petite réflexion sur le culte moderne des dieux Faitishes. Paris: Les Empêcheurs de Penser en Rond, 1996.

LATOUR, Bruno. How to be iconophilic in Art, Science and Religion? In: JONES, Caroline A.; GALISON, Peter (Ed.). Picturing science, producing art. New York: Routledge, 1998. p. 418-440.

LATOUR, Bruno. Pandora's hope: essays on the reality of science studies. Cambridge: Harvard University Press, 1999.

LATOUR, Bruno. What is iconoclash? Or is there a world beyond the image wars? In: LATOUR, Bruno; WEIBEL, Peter (Ed.). Iconoclash: beyond the image wars in science, religion and art. Karlsruhe: Center for Art and Media, 2002. p. 15-40. Catálogo. Disponível em: <http://www.bruno-latour.fr/articles/ article/84-ICONOCLASH\%20PDF.pdf>. Acesso em: 1 ago. 2007.

LYNCH, Mike; WOOLGAR, Steve (Ed.). Representation in scientific practice. Cambridge: MIT Press, 1990.

MARIN, Louis. Opacité de la peinture: essais sus la représentation. Paris: Usher, 1989.

MONDZAIN, Marie-José. Image, icône, économie: les sources byzantines de l'imaginaire contemporain. Paris: Le Seuil, 1996.

MURTHY, Anantha. Bharathipura. Madras: Macmillan, 1996.

NATHAN, Tobie. L’influence qui guérit. Paris: Odile Jacob, 1994.

OLIVIER, Christin. Une révolution symbolique. Paris: Minuit, 1991.

PINCH, Trevor. Observer la nature ou observer les instruments. Culture Technique, v. 14, p. 88-107, 1985. 
RÉAU, Louis. Histoire du vandalisme: les monuments détruits de l'art français. édition augmentée par Michel Fleury et Guy-Michel Leproux. Paris: Bouquins, 1994.

SLOTERDIJK, Peter. Critique of cynical reason. Minneapolis: University of Minnesota Press, 1987.

STEINER, George. Real presences. Chicago: University of Chicago Press, 1991.

STODDARD, Heather. Le mendiant de l'Amdo. Paris: Société d'ethnographie, 1985.

TABORDE, Denis. Vous avez-tous entendu son blasphème? Qu'en pensezvous? Dire la passion selon St Matthieu selon Bach. Ethnologie Française, v. 22, p. 320-333, 1992.

TAMEN, Miguel. Friends of interpretable objects. Cambridge: Harvard University Press, 2001.

TAUSSIG, Michael. Defacement: public secrecy and the labor of the negative. Stanford: Stanford University Press, 1999.

WIRTH, Jean. Faut-il adorer les images? La théorie du culte des images jusqu'au concile de Trente. In: DUPEUX, Cécile et al. (Ed.). Iconoclasme: vie et mort de l’image médiévale. Paris: Somogy Éditions d’art, 2001. p. 28-37.

Traduzido do inglês por Nicole Reis. 